University of Nebraska - Lincoln

DigitalCommons@University of Nebraska - Lincoln

2-2003

\title{
Host Specificity among Ancyrocephalinae (Monogenoidea) of Nebraska Sunfish
}

Megan R. Collins

University of Nebraska - Lincoln

John J. Janovy Jr.

University of Nebraska - Lincoln, jjanovy1@unl.edu

Follow this and additional works at: https://digitalcommons.unl.edu/bioscijanovy

Part of the Parasitology Commons

Collins, Megan R. and Janovy, John J. Jr., "Host Specificity among Ancyrocephalinae (Monogenoidea) of Nebraska Sunfish" (2003). John Janovy Publications. 20.

https://digitalcommons.unl.edu/bioscijanovy/20

This Article is brought to you for free and open access by the Papers in the Biological Sciences at DigitalCommons@University of Nebraska - Lincoln. It has been accepted for inclusion in John Janovy Publications by an authorized administrator of DigitalCommons@University of Nebraska - Lincoln. 


\title{
HOST SPECIFICITY AMONG ANCYROCEPHALINAE (MONOGENOIDEA) OF NEBRASKA SUNFISH
}

\author{
Megan R. Collins and J. Janovy, Jr.* \\ School of Biological Sciences, University of Nebraska Lincoln, Lincoln, Nebraska 68588-0118.
}

\begin{abstract}
This study addressed the problem of local patterns of host specificity among Ancyrocephalinae (Monogenoidea) on bass and sunfish species, when the hosts occur in different species combinations in separate ponds. One hundred fifty-three fish of the Centrarchidae, from 4 study sites in Nebraska, were collected. Host species included bluegill (Lepomis macrochirus), green sunfish (L. cyanellus), largemouth bass (Micropterus salmoides), black crappie (Pomoxis nigromaculatus), white crappie $(P$. annularis), and rock bass (Ambloplites rupestris). These fish occurred in different species combinations, depending on the pond sampled. Results indicated that several centrarchid species could inhabit the same pond and yet support distinct monogene communities. Clavunculus bursatus, Onchocleidus helicis, $O$. principalis, and Syncleithrum fusiformis were found only on largemouth bass, regardless of what other centrarchids were present in a particular pond. Haplocleidus dispar occurred on green sunfish, bluegill, largemouth bass, and black crappie, and $H$. furcatus occurred on both bluegill and largemouth bass. Onchocleidus cyanellus and $O$. ferox were found on both bluegill and green sunfish. Rock bass were present in only 1 of the 4 ponds, but were not infected with any monogenes, even though co-occurring centrarchids were often heavily infected. Largemouth bass had the most diverse ancyrocephaline communities. The degree of parasite host specificity among these monogenes was inversely related to the diversity of host species present in a particular pond. In general, the parasites were more host specific than might be inferred from the literature; parasite species did not necessarily colonize supposedly receptive host species even when the latter were present, and host relatedness was the major factor in determining whether host species shared a common parasite species.
\end{abstract}

The Centrarchidae, or sunfishes, comprises about 30 species found in North American freshwaters and includes a number of popular sport fishes. Sunfishes are routinely stocked in small ponds and lakes, resulting in various species combinations, each characteristic of a particular pond. Parasite communities of these fish can also vary, depending both on the source of fish and local environmental conditions. Hoffman (1999) reports about 90 species of Ancyrocephalinae (Monogenoidea) from centrarchids, summarizing an extensive survey literature that suggests a potentially high diversity of parasites on any 1 host species, with varying degrees of host specificity exhibited by the parasites. The present study was intended to test some of the expectations raised by Hoffman (1999) and in particular to address the question, What patterns of host specificity do the ancyrocephalines from centrarchids actually exhibit in nature when provided various opportunities for colonizing different, but confamilial, host species? In this case, host specificity is expressed as the number of host taxa occupied by a particular parasite taxon (Desdevises et al., 2001); a parasite with low host specificity would occupy a relatively large number of host taxa.

A series of ponds with different host species combinations was selected as a model system. The following hypotheses were tested: (1) if a monogene species is recovered, it will be recovered from all previously reported hosts occurring in the same pond; (2) monogene species that are host specific in 1 pond will also be host specific in another pond; and (3) patterns of parasite host specificity are independent of host community richness.

\section{MATERIALS AND METHODS}

Four ponds were used in this study. The sites were Beckius Pond $\left(41^{\circ} 12^{\prime} 30^{\prime \prime} \mathrm{N}, 101^{\circ} 37^{\prime} 04^{\prime \prime} \mathrm{W}\right)$, Dunwoody Pond $\left(41^{\circ} 15^{\prime} 25^{\prime \prime} \mathrm{N}, 101^{\circ} 34^{\prime}\right.$ $\left.43^{\prime \prime} \mathrm{W}\right)$, Humphrey Pond $\left(41^{\circ} 07^{\prime} 34^{\prime \prime} \mathrm{N}, 101^{\circ} 42^{\prime} 22^{\prime \prime} \mathrm{W}\right)$, all in Keith Coun-

Received 26 November 2001; revised 12 September 2002; accepted 12 September 2002.

* To whom correspondence should be addressed.e-mail: jjanovyl@ unl.edu. ty, western Nebraska, and Bowling Lake $\left(40^{\circ} 53^{\prime} 53^{\prime \prime} \mathrm{N}, 96^{\circ} 47^{\prime} 09^{\prime \prime} \mathrm{W}\right)$, in Lancaster County, eastern Nebraska (Table I). Fishes were collected from 1 May 1999, through 15 September 1999, by rod and reel and seining. Collection dates are as follows: Beckius-6 June, 9 June, 11 June, 24 July, 27 July, 2 August, 6 August; Dunwoody-22 June, 28 July, 30 July, 3 August, 4 August; Humphrey-14 June, 24 July; and Bowling-31 August, 8 September, 15 September. Host species combinations collected are considered correct representations of species present, on the basis of fishing history of the ponds and in the case of Beckius Pond, species observed by scuba diving and snorkeling.

Fishes were taken immediately upon collection either to the Cedar Point Biological Station (CPBS), no more than $13 \mathrm{~km}$ from any of the western collection sites, or to the University of Nebraska Biological Sciences Building, $14 \mathrm{~km}$ from Bowling Lake, where they were killed by cervical dislocation. Gills were quickly excised, placed in 1:4,000 formaldehyde (Kritsky et al., 1986) in petri dishes or small jars, and allowed to soak for up to $4 \mathrm{hr}$. Free parasites were pipetted from the soaking solution; then, each gill arch was stripped of its softened tissue, and additional parasites, if present, were collected from the preparation. Worms were fixed in alcohol-formalin-acetic acid, washed in $70 \%$ ethyl alcohol (EtOH) in water, stained very lightly with Semichon's acetocarmine, dehydrated through an EtOH series, cleared in xylene, and mounted in Damar balsam (Spectrum; Cat. \#DA105, Gardena, California).

To facilitate identification, measurements of sclerotized haptor parts were taken with an ocular micrometer, and observations of cirrus and accessory piece morphology were made, on every worm. Identifications and taxonomic and nomenclatural decisions were made using original descriptions, keys, and taxonomic summaries of Mueller (1934a, 1934b, 1936, 1937), Mizelle (1938), Mizelle et al. (1956), Price (1967), Beverley-Burton (1984, 1986), and Hoffman (1999). Parasite voucher specimens were placed in the H. W. Manter Laboratory of Parasitology (214 slides, HWML \#15493-15707), and host voucher specimens were deposited in the Division of Zoology (9 jars, \#Z-2000-13), both collections in the University of Nebraska State Museum.

\section{RESULTS}

A total of 153 fish were collected; the fish species composition, by pond, is given in Table I. Bluegill (Lepomis macrochirus), green sunfish (L. cyanellus), largemouth bass (Micropterus salmoides), black crappie (Pomoxis nigromaculatus), white crappie ( $P$. annularis), and rock bass (Ambloplites rupestris) occurred in different species combinations, depending on the pond sampled (Table I). Although it is possible that some 
Table I. Numbers of fish, by species, collected from 4 ponds in Nebraska.

\begin{tabular}{lccccc}
\hline & \multicolumn{5}{c}{ Collection site } \\
\cline { 2 - 5 } \multicolumn{1}{c}{ Fish species } & $\begin{array}{c}\text { Deckius } \\
\text { Pond }\end{array}$ & $\begin{array}{c}\text { Doody } \\
\text { wond }\end{array}$ & $\begin{array}{c}\text { Hum } \\
\text { phrey } \\
\text { Pond }\end{array}$ & $\begin{array}{c}\text { Bowling } \\
\text { Lake }\end{array}$ & Total \\
\hline Ambloplites rupestris & 11 & 0 & 0 & 0 & 11 \\
Lepomis cyanellus & 11 & 0 & 0 & 10 & 21 \\
Lepomis macrochirus & 0 & 12 & 17 & 14 & 43 \\
Micropterus salmoides & 8 & 13 & 3 & 14 & 38 \\
Pomoxis annularis & 0 & 0 & 0 & 19 & 19 \\
Pomoxis nigromaculatus & 0 & 0 & 6 & 15 & 21 \\
Total & 30 & 25 & 26 & 72 & 153 \\
\hline
\end{tabular}

centrarchid species were present but not collected in Dunwoody and Humphrey ponds, these 2 sites have been fished extensively for $20 \mathrm{yr}$ by classes at the CPBS. Only largemouth bass and bluegill sunfish have ever been collected at Dunwoody Pond, and only largemouth bass, bluegill, and black crappie have ever been collected at Humphrey Pond during the 20-yr period. Bowling Lake was seined extensively on several occasions, and the sample collected was considered representative of the fish community in that lake. Beckius Pond is a former commercial sand pit, and not only has it been fished extensively for $20 \mathrm{yr}$ by CPBS classes but snorkel and scuba surveys also have been conducted for $2 \mathrm{yr}$. The Beckius sample is considered truly representative of the host species composition.

Seven hundred forty-eight Ancyrocephalinae (Monogenoidea) were collected, representing 11 species in 7 genera. Numbers of parasites by host species are shown in Table II. Some parasite species were host specific regardless of the host species mix; for example, Clavunculus bursatus, Syncleithrum fusiformis, Onchocleidus helicis, and $O$. principalis occurred only on largemouth bass, regardless of the presence of other centrarchid species. Actinocleidus fergusoni, Haplocleidus dispar, and $O$. ferox occurred on more than 1 host genus as well as on host congeners. Onchocleidus cyanellus was genus specific to the 2 Lepomis species. Cleidodiscus vancleavei occurred on both Pomoxis species when the latter were in the same pond but only on Pomoxis species.

Table II also shows that the degree of host specificity shown by some parasite species differed according to the pond and host species mix. For example, $H$. dispar occurred on bluegill, green sunfish, and largemouth bass in Bowling Lake but only on largemouth bass in Beckius Pond, even though green sunfish were present in the latter; however, $H$. dispar occurred on both Lepomis species when they were in the same pond. Similarly, O. ferox occurred only on green sunfish in Beckius Pond (no bluegill present), only on bluegill in Humphrey and Dunwoody ponds (no green sunfish present), but on both Lepomis species plus largemouth in Bowling Lake. The Onchocleidus species exhibited varying host specificity, with $O$. ferox being the least specific ( 3 host species, 2 host genera) but with $O$. helicis and $O$. principalis occurring only on largemouth bass. Data from Table II, when averaged according to the methods of Desdevises et al. (2001), showed the numbers of centrarchid species/ parasite species (number of centrarchid species present) to be
TABLE II. Numbers of parasites recovered, by host species and by collection site.

\begin{tabular}{|c|c|c|c|c|c|c|}
\hline \multirow[b]{2}{*}{ Site/parasite } & \multicolumn{6}{|c|}{ Host species* } \\
\hline & $\begin{array}{c}A . \\
\text { rupes. }\end{array}$ & $\begin{array}{c}L . \\
\text { cyan. }\end{array}$ & $\begin{array}{c}L . \\
\text { macro. }\end{array}$ & $\begin{array}{c}\text { M. } \\
\text { salm. }\end{array}$ & $\begin{array}{c}P . \\
\text { ann. }\end{array}$ & $\begin{array}{c}P . \\
\text { nigr. }\end{array}$ \\
\hline
\end{tabular}

\section{Beckius Pond}

$\begin{array}{lrrrrrr}\text { Actinocleidus fergusoni } & 0 & 8 & - & 1 & - & - \\ \text { Clavunculus bursatus } & 0 & 0 & - & 6 & - & - \\ \text { Cleidodiscus vancleavei } & 0 & 0 & - & 0 & - & - \\ \text { Crinicleidus longus } & 0 & 3 & - & 0 & - & - \\ \text { Clavunculus bursatus } & 0 & 0 & - & 6 & - & - \\ \text { Haplocleidus dispar } & 0 & 0 & - & 36 & - & - \\ \text { Haplocleidus furcatus } & 0 & 0 & - & 0 & - & - \\ \text { Onchocleidus cyanellus } & 0 & 20 & - & 0 & - & - \\ \text { Onchocleidus ferox } & 0 & 4 & - & 0 & - & - \\ \text { Onchocleidus principalis } & 0 & 0 & - & 2 & - & - \\ \text { Onchocleidus helicis } & 0 & 0 & - & 20 & - & - \\ \text { Syncleithrum fusiformis } & 0 & 0 & - & 23 & - & -\end{array}$

Dunwoody Pond

Actinocleidus fergusoni

Clavunculus bursatus

Cleidodiscus vancleavei

Crinicleidus longus

Haplocleidus dispar

Haplocleidus furcatus

Onchocleidus cyanellus

Onchocleidus ferox

Onchocleidus principalis

Onchocleidus helicis

Syncleithrum fusiformis

Humphrey Pond

Actinocleidus fergusoni

Clavunculus bursatus

Cleidodiscus vancleavei

Crinicleidus longus

Haplocleidus dispar

Haplocleidus furcatus

Onchocleidus cyanellus

Onchocleidus ferox

Onchocleidus principalis

Onchocleidus helicis

Syncleithrum fusiformis

$$
\begin{array}{ll}
- & - \\
- & - \\
- & - \\
- & - \\
- & - \\
- & - \\
- & - \\
- & -
\end{array}
$$$$
\begin{array}{rrrr}
13 & 0 & - & - \\
0 & 2 & - & - \\
0 & 0 & - & - \\
0 & 0 & - & - \\
2 & 47 & - & - \\
0 & 0 & - & - \\
0 & 0 & - & - \\
90 & 0 & - & - \\
0 & 2 & - & - \\
0 & 6 & - & - \\
0 & 78 & - & -
\end{array}
$$

Bowling Lake

Actinocleidus fergusoni

Clavunculus bursatus

Cleidodiscus vancleavei

Crinicleidus longus

Haplocleidus dispar

Haplocleidus furcatus

Onchocleidus cyanellus

Onchocleidus ferox

Onchocleidus principalis

Onchocleidus helicis

Syncleithrum fusiformis

$\begin{array}{ll}- & - \\ - & - \\ - & - \\ - & - \\ - & - \\ - & - \\ - & - \\ - & -\end{array}$

$\begin{array}{rlll}0 & 0 & - & 0 \\ 0 & 0 & - & 0 \\ 0 & 0 & - & 0 \\ 0 & 0 & - & 0 \\ 1 & 1 & - & 0 \\ 0 & 1 & - & 0 \\ 0 & 0 & - & 0 \\ 157 & 0 & - & 0 \\ 0 & 0 & - & - \\ 0 & 4 & - & - \\ 0 & 0 & - & -\end{array}$

$*$ A. rupes. $=$ Ambloplites rupestris; L. cyan. $=$ Lepomis cyanellus; L. macro. $=$ Lepomis macrochirus; M. salm. = Micropterus salmoides; P. ann. = Pomoxis annularis; $P$. nigr. = Pomoxis nigromaculatus. Entry of 0 means that the host species was present and that no worm of the listed species was recovered. Entry of - means that the host species was not present in the pond. 
the following: Dunwoody Pond, 1.14 (2); Beckius Pond, 1.1 (3); Humphrey Pond, 1.25 (3); and Bowling Lake, 2.0 (5).

Monogene species were not equally represented in the collections. Relative abundance overall was as follows: $O$. ferox (37\%), A. fergusoni (16\%), H. dispar (14\%), O. cyanellus (12\%), S. fusiformis (10\%), O. helicis (4\%), C. vancleavei (4\%), H. furcatus (1\%), C. bursatus (1\%), O. principalis (1\%), and Crinicleidus longus (1\%). Table II also shows that a parasite species is not necessarily present in a particular pond, regardless of the presence of an appropriate host; for example, $O$. cyanellus infected bluegill in Bowling Lake but were not present on bluegill in Humphrey Pond.

Parasites identified as the same species, on the basis of copulatory structure morphology and sizes of sclerotized parts, sometimes exhibited significantly different hamulus lengths depending on pond and host species. However, for A. fergusoni, $H$. dispar, O. cyanellus, and C. vancleavei, all individual measurements, of all hamuli, were within the ranges given for their respective species in the literature. In the case of $O$. ferox, the range of measurements in this study included smaller dorsal hamuli (55-68) compared with those reported in the literature (61-72). For $O$. helicis in this study, measurements included both smaller and larger dorsal hamuli compared with those reported in the literature (28-46 in this study; 36-41 from the literature).

\section{DISCUSSION}

The major contribution of this study is the demonstration that degrees of host specificity can vary among parasites identified, on the basis of morphology, as the same species, depending on the pond in which they are found. Although this conclusion may be inferred from published accounts, no published study has systematically chosen sites for their host community makeup. The major difference among study sites of this investigation was the host species mix present, although unmeasured physical characteristics of the ponds could have contributed to the particular fish communities present, as well as to the distribution of parasites among hosts, perhaps through indirect effects on fish health. In addition, the stocking history of these ponds likely contributed to both the host and parasite species lists for each site, a possible explanation for the lack of $O$. cyanellus in Humphrey Pond. Nevertheless, from the literature (see Hoffmann, 1999, for review), one would expect that propagules of a parasite species would colonize receptive host species when the latter are present, and the results of this study show that this is not necessarily the case.

The varying level of host specificity among confamilial monogenes of marine fishes has been analyzed by Desdevises et al. (2001), who show that parasite diversity and degree of specialization are not necessarily linked. Although data from the present study are not adequate to test a hypothesis similar to that of Desdevises et al. (2001), the centrarchids do have a rich enough ancyrocephaline fauna to allow such a test, provided enough collections could be made. Previous studies have produced little evidence for historical association between some ancyrocephaline taxa and their centrarchid hosts, although host hybridization has been cited as a contributing factor (Klassen and Beverley-Burton, 1988). However, more extensive parasite surveys of several under-studied host species must be conduct- ed before analysis similar to that of Desdevises et al. (2001) can be done on the Ancyrocephalinae as a whole.

The present study obviously raises the question whether the observed host distribution of these related worms is characteristic of their distribution throughout the natural ranges of centrarchids, especially species of Lepomis and Micropterus. Although the Nebraska study sites are all artificial, and some of them were stocked, their host diversity certainly must mimic that of aquatic habitats throughout the centrarchids' natural ranges. If the observed general pattern of ancyrocephaline occurrence is repeated over the natural ranges of the hosts involved, then some reassessment of the forces acting on parasite evolution may warrant reconsideration. For example, there are evidently numerous factors in addition to host resistance and parasite physiological requirements, both of which are presumably at least partly genetically based, that dictate the distribution of the parasites in nature and, thus, the encounter between host and parasite genotypes. Such factors could include water quality, food quality and abundance, factors that result in colonization of ponds, and competition-induced stress.

A second significant contribution is the demonstration that expectations, based on literature sources, of parasite species' distributions among available hosts, are not necessarily met when a series of discrete sites containing various host species are studied. Hoffman (1999) presents the most recent and complete summary of literature reports on the Ancyrocephalinae from centrarchids (71 citations of occurrence and host records). On the basis of that summary, for example, one would expect $S$. fusiformis, $C$. bursatus, and $O$. principalis all to occur on 1 of the Lepomis species examined, but they did not, even when presented with the opportunity. On the basis of Hoffman's (1999) summary, 55\% of the ancyrocephaline-centrarchid combinations observed in this study should be expected to occur on 3 host species, $27 \%$ on 2 host species, and only $18 \%$ on 1 host species. In the present study, however, nearly half the parasite species were host specific, occurring on only 1 host species, and less than $20 \%$ occurred on 3 host species. Thus, the expectation of parasite distribution in nature, based on extensive literature survey (Hoffman, 1999), is not met. The parasites are specialists, and if they occur on more than 1 host species, those hosts are typically congeners.

A third contribution is the observation of an evident gradient of host specificity within a single genus, in this case, Onchocleidus, with $O$. ferox being the least specific ( 3 host species), $O$. cyanellus with 2 host species, and $O$. principalis and $O$. helicis with 1 host species. Similarly at the generic level, some ancyrocephalines are far more host specific than others. The centrarchid-gill monogene system should thus allow a more detailed study of the evolution of host specificity, with focus on the mechanisms involved.

\section{ACKNOWLEDGMENTS}

The authors thank the CPBS for providing laboratory space, and E. D. Dunwoody and the Central Nebraska Public Power and Irrigation District for allowing the use of ponds.

\section{LITERATURE CITED}

BeVerley-Burton, M. 1984. Monogenea and Turbellaria. In Guide to the parasites of fishes of Canada, Part 1, L. Margolis and Z. Kabata 
(eds.). Department of Fisheries and Oceans, Fisheries Research Board, Pacific Biological Station, Nanaimo, BC, Canada, 209 p.

. 1986. The taxonomic status of Actinocleidus Mueller, 1937; Anchoradiscus Mizelle, 1941; Clavunculus Mizelle et al., 1956; Anchoradiscoides Rogers, 1967; Syncleithrum Price 1967; and Crinicleidus n. gen.: North American ancyrocephalines (Monogenea) with articulating bars. Journal of Parasitology 72: 27-44.

Desdevises, Y., S. MoRAND, AND G. Oliver. 2001. Linking specialisation to diversification in the Diplectanidae Bychowsky 1957 (Monogenea, Platyhelminthes). Parasitology Research 87: 223230.

HofFMAN, G. L. 1999. Parasites of North American freshwater fishes. Comstock Publishing Associates, Cornell University Press, Ithaca, New York, $539 \mathrm{p}$.

Klassen, G. J., and M. Beverley-Burton. 1988. North American freshwater ancyrocephalids (Monogenea) with articulating haptoral bars: Host-parasite coevolution. Systematic Zoology 37: 179-189.

KRITSKy, D. C., V. E. Thatcher, AND W. A. Boeger. 1986. Neotropical Monogenea. 8. Revision of Urocleidoides (Dactylogyridae, Ancy- rocephalinae). Proceedings of the Helminthological Society of Washington 53: 1-37.

Mizelle, J. D. 1938. New species of monogenetic flukes from Illinois fishes. American Midland Naturalist 19: 465-470.

-, P. S. Stokely, B. J. Jaskoski, A. P. Seamster, and L. H. Monaco. 1956. North American freshwater Tetraonchinae. American Midland Naturalist 55: 162-179.

Mueller, J. F. 1934a. Parasites of Oneida Lake fishes. Part IV. Additional notes on parasites of Oneida Lake fishes, including descriptions of new species. Roosevelt Wild Life Bulletin 3: 335-373.

. 1934b. Two new trematodes from Oneida Lake fishes. Transactions of the American Microscopical Society 53: 231-236.

1936. New gyrodactylid trematodes from North American fishes. Transactions of the American Microscopical Society 55: 457464.

1937. Further studies on North American Gyrodactyloidea. American Midland Naturalist 18: 207-219.

Price, C. E. 1967. Notes on the trematode genera Cleidodiscus and Urocleidus from gills of Lepomis auritus. Quarterly Journal of the Florida Academy of Science 30: 61-67. 